\title{
PERANAN INSPECTOR OF SCHOOLS (NAZIR SEKOLAH) DALAM MENINGKATKAN MUTU PENDIDIKAN DI NEGERI PERAK, 1890-1900
}

\author{
Siti Aisyah Binti Abdullah
}

\begin{abstract}
This article discusses the welfare strategy that was implemented by Inspector of Schools in improving the quality of education in the state of Perak during the period between the year 1890 to 1900. In this context, the welfare strategy refers to the approach employed by Inspector of Schools in the effort to improve the quality of education in the state of Perak, which is by winning the hearts of teachers, students and parents. The welfare strategy that was implemented by H.B. Collinge as the Inspector of Schools in Perak covers various aspects like raising teachers' salary, introducing retirement scheme and effective teaching methods, establishing Malay Teaching College specifically for Malay teachers and etc. This study's research question will explore the extent to which the welfare strategy employed by Collinge had let to great impact on the direction of English and Malay vernacular education in that state. Overall, the welfare strategy that was implemented by Collinge succeeded in developing the education system in the Perak state. This was clearly observed through the increase in students enrollment and in the number of schools in the state that kept on rising on a daily basis. In fact, the strategy put forth by Collinge, which is to win the hearts of teachers through incentives like pay raise and promotions motivated them to continue serving with excellence. Besides that, the softcore welfare strategy were also able to encourage parents to send their children to school without being forced to.
\end{abstract}

\section{Pengenalan}

Perbincangan mengenai peranan yang dimainkan oleh Inspector of Schools bukanlah satu perkara baru. ${ }^{1}$ Ini memandangkan perbincangan mengenai peranan Inspector of Schools secara umumnya telah pun di bincangkan oleh D. D. Chelliah dalam kajiannya A History of The Educational Policy of The Straits Settlements with Recommendations for a New System Based on Vernaculars. Chelliah membincangkan tentang kedudukan dan peranan Inspector of Schoolsdi Negeri-negeri Selat (NNS) pada tahun 1870-an. A. M. Skinner merupakan Inspector of Schools yang pertama di NNS. ${ }^{2}$ Selain Chelliah, Rex Stevenson dan Barlow juga memuatkan peranan yang dimainkan oleh Skinner dalam membangunkan pendidikan vernakular Melayu di NNS. ${ }^{3}$ Tidak dapat dinafikan bahawa kajian mengenai Skinner ini juga membawa inspirasi kepada perbincangan mengenai peranan yang dimainkan oleh $\mathrm{H}$. B. Collinge iaitu Inspector of Schools di negeri Perak.

Dalam konteks negeri Perak misalnya, strategi yang dilaksanakan oleh Collinge ini sebenarnya dilihat agak berbeza dengan NNS dan negeri-negeri Melayu yang lain. Hal ini kerana Inspector of Schools di NNS dan negeri-negeri Melayu yang lain menggunakan hukuman dan dendaan kepada guru, pelajar dan ibu bapa di negeri masing-masing sekiranya tidak mengikut peraturan. Walau bagaimanapun, kaedah ini tidak menjadi pilihan Collinge. Dalam pada itu, S. Barlow menerusi kajiannya, Swettenham menyatakan bahawa Collinge dan guru pelawat Melayu kerap memantau dan memeriksa setiap sekolah di negeri Perak, malah mereka juga melawat ibu bapa kanak-kanak Melayu untuk memujuk mereka supaya menghantar anak-anak mereka ke sekolah. ${ }^{4}$ Pendapat beliau turut disokong oleh Rex Stevenson yang didapati turut menekankan perkara yang sama dalam kajiannya. Kajian Stevenson juga mendapati bahawa Collinge sememangnya berjiwa seorang guru sehinggakan 
beliau sanggup memulakan usaha untuk menubuhkan sebuah maktab perguruan untuk guruguru Melayu di negeri Perak selepas sahaja beliau menerima jawatan di Jabatan Pelajaran Negeri Perak pada tahun 1890. Kajian Stevenson menggambarkan bahawa Collinge tidak pernah berputus asa dalam mencapai hasratnya untuk menjadikan guru-guru Melayu lebih berkualiti berbanding tahun-tahun sebelumnya. Kesemua bentuk pendekatan yang digunakan oleh Collinge inilah yang akan diketengahkan dalam kajian ini dengan melihat kemampuan beliau dalam memberikan kesan kepada perkembangan sistem pendidikan di negeri Perak sama ada dari segi jumlah kedatangan murid ke sekolah mahupun pencapaian atau prestasi yang ditunjukkan oleh murid-murid dan juga guru-guru di sekolah-sekolah Inggeris dan sekolah-sekolah vernakular Melayu.

\section{Peranan H.B. Collinge}

Perlantikan Collinge sebagai Inspector of Schools Perak pada tahun 1890, dikatakan bertitik tolak daripada cadangan Sir Cecil Clementi Smith, Gabenor Negeri-Negeri Selat. Sebenarnya, Smith mahu Collinge dilantik menjadi Inspector of Schoolsnegeri Perak dan Selangor. Idea ini turut disokong oleh Lord Knutsford iaitu pegawai di Pejabat Tanah Jajahan (PTJ). ${ }^{5}$ Walau bagaimanapun, hal ini tidak dipersetujui oleh W. E. Maxwell iaitu Residen British di Selangor. Hal ini kerana beliau tidak mahu berkongsi Inspector of Schools dengan musuhnya iaitu, Swettenham. ${ }^{6}$ Lebih-lebih lagi, Maxwell pada ketika itu telah pun mengambil langkah-langkah untuk merekrut Revd. F. H. Haines untuk menjadi Inspector of Schools di negeri Selangor. ${ }^{7}$ Hal ini menyebabkan Collinge dilantik menjadi Inspector of Schools hanya untuk negeri Perak.

Sebenarnya, Collinge merupakan seorang guru di sekolah Inggeris di negeri Melaka sebelum dilantik menjadi Inspector of Schools pada tahun 1890. Peranan Collinge dalam membangunkan sistem pendidikan di Perak dilihat begitu signifikan kerana Jabatan Pelajaran Negeri Perak menjadi lebih kukuh semasa jabatan tersebut berada di bawah pimpinannya. ${ }^{8}$ Hal ini dapat dibuktikan daripada kenyataan Swettenham seperti berikut:

His Excellency's interest in our education work obtained for us the appointment of an Inspector (Mr. H. B. Collinge, formerly in Malacca) last May, and the result of his zealous exertions has been such that I can for the first time say that the cause of education has been materially advanced, and the prospects for the future are decidedly hopeful. ${ }^{9}$

Kenyataan di atas jelas membuktikan sistem pendidikan di negeri Perak mengalami perubahan dalam masa yang singkat selepas kehadiran Collinge di Jabatan Pelajaran Perak. Hal ini turut dipermudahkan kerana beliau berpengetahuan dalam bidang pendidikan apatah lagi beliau pernah bertugas sebagai guru di England dan Melaka. Selain itu, beliau juga mempunyai kemahiran menulis buku tentang kaedah pengajaran (pedagogi). Hal yang berkaitan dengan penulisan buku pedagogi akan dijelaskan dengan lebih mendalam nanti (di bawah tajuk sekolah vernakular Melayu). Hal ini membuktikan beliau amat memahami psikologi guru, pelajar dan ibu bapa Melayu. ${ }^{10}$

Di samping itu, sebelum Collinge menyandang jawatannya itu, terdapat seorang pegawai perkhidmatan awam yang berkelayakan rendah telah ditugaskan untuk memantau dan memeriksa sekolah-sekolah di negeri Perak. Di bawah pemantauannya, iaitu pada tahun 1888, hanya terdapat 4 buah sekolah Inggeris dan 8 buah sekolah vernakular Melayu di negeri Perak. Kurangnya pemantauan di sekolah vernakular Melayu bukan sahaja membawa kepada purata kehadiran murid menurun, malah menyebabkan proses pengajaran dan pembelajaran dalam kalangan guru juga menjadi tidak seragam. Walau bagaimanapun, hal ini berubah selepas Collinge menggantikannya pada tahun 1890. Jadual 1.1 menunjukkan 
perbandingan antara sekolah-sekolah Inggeris dengan sekolah-sekolah vernakular Melayu sebelum dan selepas Collinge menjadi Inspector of Schools.

Jadual 1: Perbandingan Antara Sekolah-Sekolah Inggeris Dengan Sekolah-Sekolah Vernakular Melayu Di PerakSebelum Dan Selepas Collinge Menjadi Inspector of Schools

\begin{tabular}{lllllllllllll}
\hline Sekolah & 1888 & 1889 & 1890 & 1891 & 1892 & 1893 & 1894 & 1895 & 1896 & 1897 & 1898 & 1899 \\
\hline Inggeris & 2 & 3 & 4 & 5 & 6 & 6 & 6 & 7 & 7 & 8 & - & 14 \\
$\begin{array}{l}\text { Anglo } \\
\text { Tamil }\end{array}$ & 2 & 3 & 1 & 3 & 3 & 2 & 1 & 2 & 2 & 2 & - & 2 \\
$\begin{array}{l}\text { Anglo } \\
\text { Melayu }\end{array}$ & - & 1 & 0 & 0 & 0 & 0 & 0 & 0 & 0 & 0 & - & 0 \\
Melayu & 8 & 8 & 32 & 50 & 59 & 68 & 75 & 84 & 88 & 98 & - & 98 \\
JUMLAH & 15 & 18 & 39 & 60 & 70 & 78 & 85 & 96 & 99 & 112 & 113 & 116 \\
\hline
\end{tabular}

Sumber: CO438/1, Annual Report on the State of Perak for the Year 1889, 1890, 1891, 1892, 1893 dan 1894.

Berdasarkan Jadual 1 di atas, didapati semasa berada di bawah pemantauan Collinge, sekolah-sekolah vernakular Melayu berkembang dengan begitu pesat, iaitu daripada 32 buah sekolah pada tahun 1890 kepada 98 buah sekolah pada tahun 1899. Apa yang dapat disimpulkan di sini adalah dari tahun 1890 hingga tahun 1900, sekolah-sekolah vernakular Melayu mendapat perhatian serius daripada kerajaan British di negeri Perak jika berbanding dengan sekolah Inggeris dan sekolah vernakular lain. Langkah ini diberi penekanan untuk mengurangkan buta huruf dalam kalangan murid-murid Melayu di kawasan luar bandar. Bahkan ia juga menjadi key policy untuk menawan hati kerabat diraja dan bangsawan Melayu di Perak.

\section{Sekolah Vernakular Melayu}

Terdapat beberapa faktor mengapa sekolah-sekolah vernakular Melayu boleh berkembang dengan pesat di bawah pimpinan Collinge di negeri Perak. Pertama, kerajaan British mengutamakan pendidikan peribumi memandangkan Sultan Perak pada ketika itu iaitu Sultan Idris Murshidul Aadzam sangat mengambil berat terhadap pendidikan rakyat Melayu. ${ }^{11}$ Ini kerana, pengalaman baginda sebagai pendidik pada tahun 1880-an telah membolehkan baginda berminat dalam pendidikan vernakular Melayu. Laporan Klang 580/83 jelas menerangkan tentang peranan Sultan Idris dalam membangunkan pendidikan vernakular Melayu di Klang. Sultan Idris dikatakan mendapat pujian daripada Residen British Selangor kerana mengurangkan buta huruf murid-murid Melayu di Sekolah Vernakular Melayu Klang pada tahun 1883. ${ }^{12}$ Jelas di sini, pengalaman baginda sebagai pendidik secara tidak langsung telah merancakkan lagi pembangunan pendidikan di negeri Perak menerusi usaha gigih Collinge.

Kedua, Collinge menggabungkan kelas agama di sekolah-sekolah vernakular Melayu supaya purata kehadiran murid Melayu ke sekolah meningkat. Dalam laporannya, Frank Swettenham menyebut bahawa bilangan sekolah vernakular Melayu dinaikkan dengan menggabungkan kelas agama dengan kelas pendidikan vernakular Melayu pada tahun $1890 .{ }^{13}$ Jadual 1 jelas membuktikan peningkatan bilangan sekolah vernakular Melayu dari lapan buah pada tahun 1888 kepada 32 buah pada tahun 1890.Langkah ini diambil bagi memenangi hati ibu bapa Melayu yang bimbang anak mereka akan diKristiankan sekiranya belajar di sekolah 
vernakular Melayu. Kebimbangan ini berlaku akibat Kristianisasi yang berlaku di sekolah vernakular Melayu terutama di Singapura. ${ }^{14}$

Ketiga, Collinge juga menggunakan guru-guru agamayang benar-benar berkualiti untuk mengajar di sekolah vernakular Melayu. ${ }^{15}$ Guru-guru agama yang dipilih bukan sahaja dikehendaki untuk menguasai kemahiran dan kebolehan untuk membaca al-Quran dan memahami sejarah Nabi Muhammad SAW, bahkan mereka juga digunakan sebagai saluran untuk memperkenalkan 3M (membaca, menulis, dan mengira) di sekolah-sekolah vernakular Melayu. ${ }^{16}$ Guru-guru agama dilantik untukmenjadi guru Melayu dan agama kerana masyarakat Melayu amat menghormati mereka. Walaupun pada mulanya guru-guru agama dikehendaki mengajar pendidikan Melayu dan pendidikan agama pada sesi yang sama, namun kelas-kelas berkenaan terpaksa dipisahkan bagi memajukan pendidikan Melayu. Hal ini menyebabkan pendidikan sekular Melayu diajar pada sebelah pagi, manakala pendidikan agama diajar pada sebelah petang. Langkah ini bertujuan agar murid-murid Melayu menerima pendidikan vernakular Melayu yang lebih efektif.

Selain itu, Collinge turut mendapatkan bantuan daripada Pegawai Daerah dan Penghulu bagi memberi kesedaran kepada ibu bapa Melayu yang didapati enggan membenarkan anak mereka bersekolah. ${ }^{17}$ Bahkan ada juga ibu bapa Melayu yang tidak membenarkan anak-anak mereka menghabiskan Tahun IV (Tahun IV dianggap pelajaran tertinggi bagi anak-anak lelaki Melayu pada tahun 1890-an). Masalah ini berlaku disebabkan ada di antara ibu bapa yang menggunakan tenaga anak-anak lelaki mereka untuk membantu mengusahakan tanah pertanian yang menjadi punca pendapatan seharian. Hulbert Berkeley, yang merupakan Pemangku Magistret di daerah Kuala Kangsar telah meminta bantuan Sultan Idris untuk memujuk masyarakat Melayu menghantar anak mereka ke sekolah. Hal ini jelas dilihat daripada laporan Collinge:

The great interest which Mr. Hulbert always took in the Kuala Kangsar schools prompted him to urge that His Highness the Sultan should be asked to write a letter inviting the people to send their children to school. ${ }^{18}$

Selain itu, Hulbert juga mengesyorkan tukang kayu dan tukang besi di tempatkan di setiap sekolah agar kanak-kanak lelaki Melayu mempelajari ilmu pengetahuan dan kemahiran yang berguna untuk meneruskan kelangsungan hidup mereka. Di sini dapat dilihat kaedah yang digunakan oleh Collinge bagi menarik minat ibu bapa Melayu adalah lebih kepada bentuk toleransi di mana beliau tidak menggunakan kaedah seperti denda dan hukuman kepada ibu bapa Melayu seperti mana yang diamalkan di negeri Selangor dan Negeri Sembilan. ${ }^{19}$

Selain itu, para penghulu di negeri Perak juga memainkan peranan dengan memujuk ibu bapa Melayu supaya menghantar anak-anak mereka ke sekolah. Mereka juga tidak mengenakan saman sekiranya ibu bapa Melayu enggan menurut perintah. Dalam erti kata yang lain, mereka bertindak sebagai jurucakap kampung. Stevenson menerusi kajiannya mendapati bahawa kerajaan British bergantung harap pada para penghulu untuk menyampaikan hasrat mereka. ${ }^{20}$ Oleh itu, para penghulu digunakan dalam usaha untuk memberikan kesedaran kepada masyarakat Melayu di kawasan luar bandar tentang kepentingan pendidikan kepada masyarakat Melayu itu sendiri. ${ }^{21}$

Tambahan pula, Collinge dilihat tidak meminggirkan pendidikan dalam kalangan anak-anak Melayu meskipun dasar British pada masa itu lebih kepada menjaga kepentingan pendidikan dalam kalangan anak-anak bangsawan dan kerabat diraja. Beliau berpendapat bahawa sekolah seharusnya menjadi platform terbaik kepada pelajar Melayu untuk belajar mengenai disiplin, kebersihan dan ketepatan masa. Hal ini dapat dibuktikan melalui kenyataan berikut: 
I do not advocate under present conditions, a greater expenditure in connection with Malay schools. The best attainable advantages of these schools are that Malay children should be taugtto be clean, punctual and amenable to discipline and that they should be brought under medical inspection. The greatest aim should be to make the children useful in their homes and callings. ${ }^{22}$

Berdasarkan kenyataan di atas, terbukti bahawa Collinge berharap agar generasi muda Melayu menjadi anak yang berguna kepada ibu bapa Melayu. Ketiga-tiga aspek yang ditekankan oleh Collinge iaitu kebersihan, ketepatan masa dan disiplin akan membentuk tingkah laku dalam kalangan pelajar Melayu. Selain itu, pembentukan tingkah laku yang baik juga diharap dapat mengelakkan mereka daripada menimbulkan masalah dalam bilik darjah. Bahkan disiplin yang ditanamkan dalam kalangan pelajar menarik minat mereka untuk belajar dan seterusnya memberi ruang kepada mereka untuk menjadi masyarakat yang progresif.

Seterusnya, Collinge jugamenghasilkan Manual for Teaching Romanised Malay dan Teachers Manual dalam usaha beliau untuk mendedahkan kaedah pengajaran yang betul dan berkesan memandangkan antara tahun 1890 hingga tahun 1897 masih belum ada pusat maktab perguruan yang boleh dijadikan sebagai rujukan. ${ }^{23}$ Hal ini dikatakan demikian kerana guru agama yang tidak pernah dilatih dalam mata pelajaran Aritmetik didapati menghadapi kesukaran untuk mengajar 3M (membaca, menulis, dan mengira). ${ }^{24}$ Selain daripada menggunakan Manual for Teaching Romanised Malay dan Teachers Manual untuk kegunaan guru-guru di sekolah-sekolah vernakular Melayu di negeri Perak, kedua-dua buah buku ini juga dijadikan sebagai buku rujukan oleh guru-guru di negeri Selangor. Hal ini dapat dibuktikan menerusi fail yang bernombor Selangor 3694/94 yang ada mencatatkan sebanyak 200 salinan Manual of Romanised Malay for Use in Government Schools yang telah dihantar kepada Jabatan Pelajaran Negeri Selangor. ${ }^{25}$ Terbuktilah di sini bahawa Collinge mengambil inisiatifnya yang tersendiri dalam melakukan perubahan yang besar terhadap kaedah pengajaran dalam kalangan guru di sekolah-sekolah vernakular Melayu.

Selain itu, kajian Stevenson juga mendedahkan sebelum kehadiran Collinge, negeri Perak telah merekrut guru terlatih dari NNS bagi mengatasi masalah kekurangan guru terlatih yang serius di sekolah vernakular Melayu. Misalnya, lima atau enam orang guru Melayu yang dihasilkan dari Maktab Perguruan Melayu Singapura telah direkrut pada tahun 1880an. ${ }^{26}$ Walau bagaimanapun, bekalan guru terlatih yang dibawa masuk ke Perak tidak mampu memenuhi permintaan yang tinggi daripada sekolah-sekolah vernakular Melayu. Hal ini kerana, di NNS sendiri, perkembangan sekolah vernakular Melayu terutama di Melaka dan Pulau Pinang telah membawa kepada permintaan tinggi bagi guru-guru yang dikeluarkan dari Maktab Perguruan Melayu Singapura. Bahkan,sikap guru-guru terlatih dari NNS yang tidak bersedia berkhidmat di luar NNS juga menyukarkan untuk mendapatkan guru terlatih. 
Masalah kekurangan guru Melayu juga berlaku akibatbidang profesion perguruan kurang diminati oleh pelajar lepasan Melayu di negeri Perak. Ini kerana mereka lebih berminat untuk mengikut jejak langkah ibu bapa mereka. Keadaan ini menyebabkan negeri Perak menghadapi masalah kekurangan guru Melayu yang sangat serius. Hal ini dapat dibuktikan daripada graf di bawah:

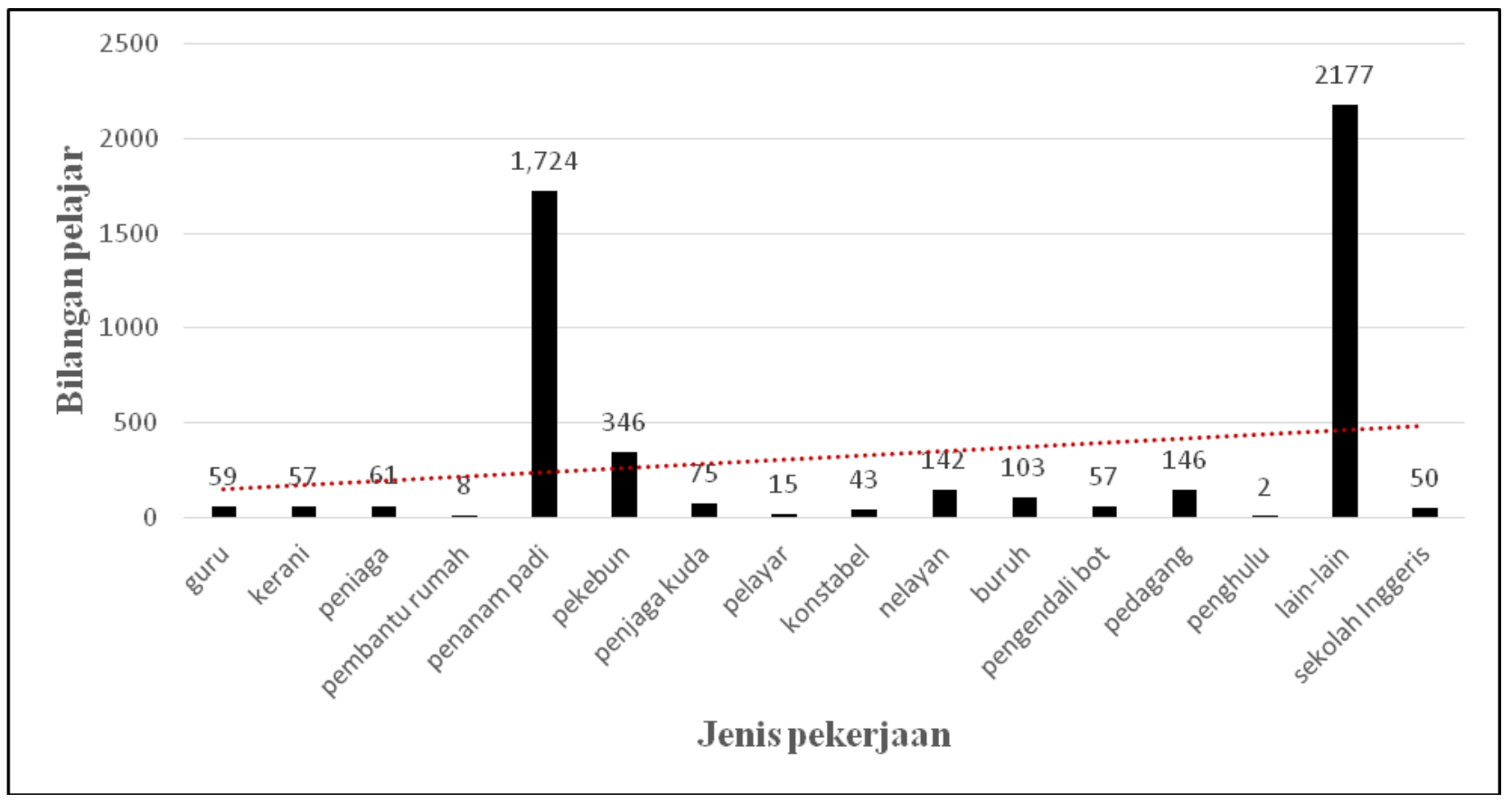

Graf 1: Pemilihan Kerja Selepas Keluar Dari Sekolah Vernakular Melayu Pada Tahun 1896

Sumber: C.O.438/1, Laporan Tahunan negeri Perak bagi tahun 1896, W.H. Treacher, Residen British, Taiping, Perak: Dicetak dengan menggunakan mesin cetak kerajaan, hlm. 23.

Graf 1 di atas menunjukkan terdapat 16 jenis bidang pekerjaan menjadi pemilihan anak-anak Melayu yang menamatkan pengajian di sekolah vernakular Melayu. Daripada bilangan tersebut, murid-murid lepasan sekolah vernakular Melayu lebih cenderung untuk bekerja sebagai peniaga, pelombong $(30.30 \%)$ dan penanam padi $(24 \%)$. Sebaliknya, murid-murid yang memilih untuk menjadi guru hanyalah sebanyak $0.8 \%$ (59 daripada 7,183 orang murid lepasan sekolah vernakular Melayu). ${ }^{27}$ Bagi mengatasi masalah kekurangan guru terlatih di negeri Perak, Collinge telah mengambil langkah selepas sahaja beliau mengambil jawatan di Jabatan Pelajaran Negeri Perak. Pada tahun 1890, beliau telah menghantar kertas cadangan untuk menubuhkan sebuah maktab perguruan Melayu di negeri Perak kepada Gabenor NNS, iaitu Sir Cecil Clementi. Walau bagaimanapun, idea ini telah ditolak oleh Clementi dan mencadangkan agar calon guru dari negeri Perak di hantar ke Maktab Perguruan Melayu Singapura untuk mengikuti latihan perguruan. ${ }^{28}$ Namun, saranan Clementi tidak berjaya kerana ibu bapa Melayu enggan membenarkan anak-anak mereka meninggalkan kampung halaman mereka. Ini kerana masyarakat Melayu mempunyai ikatan emosi dan sentimen yang kuat terhadap ibu bapa dan juga agama. ${ }^{29}$ Apatah lagi, ibu bapa Melayu bimbang anak mereka akan di Kristiankan kerana Pengetua Maktab Perguruan Melayu Singapura adalah pegawai Eropah. 
Melihat situasi yang semakin rumit, Collinge mengambil langkah tegas dengan memberi amaran kepada pihak British mengenai kesan buruk yang akan berlaku sekiranya tenaga guru terlatih tidak dapat disediakan. Collinge seterusnya telah membawa usul berkaitan ketiadaan guru terlatih di sekolah vernakular Melayu berserta implikasinya terhadap aspek pendidikan dalam Laporan Tahunan 1895. Beliau terpaksa memberi amaran kepada Kerajaan British kerana dua sebab utama. Pertama, negeri Perak menghadapi masalah kekurangan guru yang sangat serius berikutan pertambahan pendaftaran murid daripada 2,616 orang pada tahun 1892 kepada 3,783 orang pada tahun $1895 .{ }^{30}$ Kedua, Maktab Perguruan Melayu Singapura telah ditutup pada tahun 1895 dan keadaan ini menyebabkan negeri Perak menghadapi kekurangan bekalan guru terlatih. Oleh itu, Collinge telah menulis surat kepada Residen British Perak, iaitu W. H. Treacher pada 6 Oktober 1896 supaya memperuntukkan wang sebanyak $\$ 1,000.00$ untuk menubuhkan sebuah maktab perguruan Melayu di Taiping. ${ }^{31}$ Collinge juga menjelaskan pada peringkat awal, sebuah bangunan akan disewa untuk memberi latihan perguruan kepada calon guru Melayu, manakala maktab perguruan hanya akan dibina sekiranya skim ini berjaya.

Selain itu, Treacher juga berminat dengan skim yang dicadangkan oleh Collinge. Oleh itu, beliau telah menulis surat kepada Residen Jeneral, iaitu Frank Swettenham pada 12 Oktober 1896 dan mencadangkan supaya maktab perguruan tersebut turut digunakan untuk kegunaan calon-calon guru daripada semua negeri Melayu. ${ }^{32}$ Walau bagaimanapun, Swettenham tidak memberikan sebarang respons kepada Treacher selama setahun, namun pada tahun 1897, High Commissioner, iaitu Sir Charles Mitchell telah memberi reaksi yang positif tentang cadangan tersebut. Namun, beliau tidak mahu kos penyelenggaraan maktab berkenaan dijadikan sebagai Federal Chargemalah beliau mahu ianya dikongsi oleh negerinegeri yang mengambil bahagian dalam skim tersebut. ${ }^{33}$ Akhirnya, Sekolah Perguruan Taiping ditubuhkan pada 16 Mei 1898 dengan bilangan calon guru seramai 10 orang (lima orang dari Perak dan lima orang dari Selangor). Kursus perguruan selama dua tahun ini digabungkan dengan pendidikan teknikal. Dalam hal ini, negeri Perak dan Selangor telah berkongsi anggaran perbelanjaan bagi skim tersebut. Jumlah anggaran perbelanjaan bagi tahun 1898 adalah sebanyak $\$ 2,300.00$ setahun dan telah meningkat kepada $\$ 3,120.00$ pada tahun $1899 .{ }^{34}$ Berdasarkan hujah di atas, jelas ternyataCollinge sememangnya bersungguhsungguh ingin menjaga kebajikan guru-guru dan murid-murid di semua sekolah vernakular Melayu. ${ }^{35}$

Sungguhpun begitu, Collinge juga memastikan tenaga pengajar yang dilantik di Sekolah Perguruan Taiping mempunyai kelayakan tinggi. Sheikh Nasir dilantik sebagai Pengetua Sekolah Perguruan Taiping kerana beliau mempunyai pengalaman yang cukup lama dalam bidang pengajaran bahkan disanjung tinggi oleh masyarakat Melayu. Sheikh Nasir juga pernah menjadi guru di sekolah vernakular Melayu Taiping sebelum menerima kenaikan pangkat menjadi Guru Pelawat Melayu. ${ }^{36}$ Begitu juga, pembantu Sheikh Nasir dipilih dalam kalangan guru Melayu yang mempunyai kemahiran dalam pendidikan teknik dan vokasional. Muhammad Ariff yang merupakan guru di sekolah vernakular Melayu Krian dilantik sebagai Penolong kepada Sheikh Nasir. Beliau mempunyai ilmu pengetahuan dan kemahiran dalam bidang pertukangan. ${ }^{37}$ Bagi meningkatkan mutu pengajaran di Sekolah Perguruan ini, Collinge juga menawarkan gaji yang tinggi kepada Pengetua dan guru penolong. Misalnya, Sheikh Nasir ditawarkan gaji bulanan sebanyak \$55, manakala Muhammad Ariff pula di bayar gaji bulanan sebanyak \$30. Apa yang dapat disimpulkan di sini adalah, Collinge memilih guru Melayu yang mempunyai kelayakan tinggi sebagai tenaga pengajar di Sekolah Perguruan Taiping bagi menghasilkan guru Melayu yang berkelayakan dalam bidang pengajaran, pendidikan teknik dan vokasional. 
Menyedari pentingnya pendidikan vernakular Melayu di kawasan luar bandar, Collinge telah berusaha meningkatkan gaji guru di sekolah-sekolah vernakular Melayu. Justeru itu, Collinge memastikan gaji yang diterima oleh guru-guru di sekolah vernakular Melayu di negeri Perak, lebih tinggi daripada guru-guru Melayu di negeri-negeri Melayu yang lain. Hal ini bukan sahaja bertujuan untuk mendorong guru-guru Melayu di negeri Perak meningkatkan mutu pengajaran, malah untuk memujuk lebih ramai lagi murid-murid Melayu menjadi guru. Sebagai contoh, gaji yang diterima oleh Guru Besar di Sekolah Vernakular Melayu Taiping, Perak adalah sebanyak \$25.00 sebulan, manakala gaji yang diterima oleh Guru Besar di Sekolah Vernakular Melayu Kuala Klawang, Negeri Sembilan hanyalah sebanyak \$15.00 sebulan pada tahun 1893. Begitu juga, guru-guru penolong di Changkat Jering dan Kampong Dew pula layak menerima gaji sebanyak $\$ 20.00$ sebulan. ${ }^{38}$

Sungguhpun orang Melayu dikatakan terlalu terikat dan berpegang teguh kepada sistem adat dan tidak membenarkan pendidikan kanak-kanak perempuan Melayu, namun begitu Collinge telah berusaha memajukan pendidikan kanak-kanak perempuan Melayu. Hal ini dapat dibuktikan apabila Collinge menaikkan gaji guru-guru wanita Melayu di negeri Perak. Sebagai contohnya, guru-guru wanita yang mengajar di sekolah-sekolah di Jalan Bahru, Bukit Gantang, dan Tanjung Piandang dinaikkan gaji tahunan kepada \$180.00, iaitu lebih tinggi daripada gaji guru-guru wanita di sekolah Tamil di Gula Estate yang hanya menerima gaji sebanyak $\$ 120.00$ setahun. ${ }^{39}$ Jelas, kenaikan gaji ini dibuat sebagai salah satu cara untuk meramaikan lagi jumlah guru wanita Melayu di Perak. Selain itu, penyertaan pelajar perempuan Melayu ke sekolah juga dapat memberi peluang kepada mereka untuk meningkatkan kedudukan mereka melalui pendidikan.Usaha Collinge yang menggalakkan kemasukan pelajar perempuan Melayu ke sekolah dilihat agak berjaya. Hal ini dapat diperhatikan pada tahun 1894 di mana terdapat seramai lapan orang pelajar perempuan Melayu yang telah berkahwin dan telah mengikuti pengajian di sekolah vernakular Melayu untuk mendapatkan ilmu pengetahuan dan kemahiran dalam jahitan dan masakan. ${ }^{40}$ Dalam konteks ini, jelas kemahiran yang dipelajari di sekolah vernakular Melayu perempuan bukan sahaja dapat membantu para pelajar perempuan Melayu untuk menguruskan rumahtangga malah juga menambahkan lagi sumber pendapatan keluarga mereka.

Walaupun pada abad ke-19, kerajaan British tidak menyediakan skim pencen kepada guru-guru tempatan yang akan bersara, akan tetapi Collinge telah berusaha menjaga kebajikan guru-guru tempatan dengan menggalakkan guru-guru di negeri Perak supaya berjimat-cermat dan mendepositkan sejumlah wang secara sukarela dalam bank simpanan dari semasa ke semasa. ${ }^{41}$ Kerajaan British di Negeri-negeri Melayu Bersekutu hanya menyediakan skim pencen kepada guru-guru Eropah yang mempunyai perkhidmatan yang berkualiti. Sebagai contohnya, Mr. Green, Guru Besar Central School Taiping menerima skim pencen kerana beliau mempunyai perkhidmatan yang berkualiti bahkan kesemua pelajar di bawah bimbingannya telah lulus peperiksaan Standard VII dengan keputusan yang sangat menggalakkan. ${ }^{42}$ Collinge berharap pelaburan dalam bank simpanan ini dapat menjamin kebajikan guru-guru apabila mereka sudah bersara. Dilaporkan bahawa pada tahun 1892, sebanyak \$344.38 telah disimpan dalam Bank Simpanan Kerajaan dan telah dimasukkan ke dalam Perbendaharaan pada suku tahunan. ${ }^{43}$ Walau bagaimanapun, urusan menyimpan atau mengeluarkan wang akan dihentikan secara automatik sekiranya seseorang guru itu meninggalkan perkhidmatan tanpa memberikan sebarang notis kepada kerajaan British. Dalam konteks ini, ternyata dana ini bukan sahaja dikutip untuk menjamin kebajikan guruguru, bahkan pada masa yang sama bertujuan untuk memupuk sikap bertanggungjawab dalam kalangan guru Melayu itu sendiri. 


\section{Sekolah Inggeris}

Walaupun peningkatan purata pendaftaran murid di sekolah-sekolah Inggeris didapati semakin ketara selepas tahun 1889, namun kerajaan British di negeri Perak sentiasa berusaha untuk memastikan sistem pendidikan Inggeris yang bermutu tinggi hanya disediakan di beberapa buah sekolah Inggeris seperti di Central School Taiping. Sebaliknya, di sekolahsekolah Inggeris yang lain, sistem pendidikan bermutu rendah disediakan bagi menjaga kepentingan kerajaan British di negeri Perak. Hal ini dapat dibuktikan dengan tindakan kerajaan British yang memperuntukkan sebanyak \$9,192 (69 peratus daripada \$13, 347) kepada Daerah Larut jika dibandingkan dengan daerah Kuala Kangsar dan Hilir Perak masing-masing menerima $\$ 1,500 .^{44}$ Selain itu, Frank Swettenham dalam laporan tahunan Perak pada tahun 1890 menyatakan bilangan sekolah Inggeris pada tahun tersebut adalah sebanyak tujuh buah, manakala purata kehadiran murid adalah seramai 246 orang. ${ }^{45}$ Walau bagaimanapun, pada tahun 1899, bilangan sekolah Inggeris telah meningkat kepada 14 buah, manakala purata kehadiran murid telah meningkat kepada 769 orang. ${ }^{46}$

Faktor utama bilangan sekolah Inggeris meningkat dengan pesat pada tahun 1899 disebabkan oleh pembukaan grant-in-aid (sekolah mubaligh). Didapati sebanyak lapan buah sekolah mubaligh mendapat bantuan daripada kerajaan British, manakala empat buah sekolah mubaligh dibantu oleh Methodist Episcopal Mission dan Roman Catholic Mission. Government Girl's School di Taiping dibantu oleh Methodist Mission School. Kesemua badan gereja tersebut memberi sumbangan dalam usaha untuk meningkatkan mutu sistem pendidikan di sekolah-sekolah di bawah kawalan mereka. Dalam laporan tahunan 1896, Collinge memuji kemajuan yang luar biasa yang diperolehi oleh murid-murid di Methodist Episcopal Missiondi Ipoh. ${ }^{47}$ Ditegaskan di sini, susulan daripada laporan Collinge, kerajaan Briitsh menawarkan sebanyak $\$ 434.00$ sebagai geran keputusan dalam peperiksaan berkenaan. $^{48}$

Selain itu, Collinge juga memberi penghargaan dalam bentuk pemberian cuti kepada Pengetua wanita di Convent Mission Girls' School kerana menaikkan nama sekolah. Hal ini dapat dibuktikan pada tahun 1895 apabilaPengetua berkenaan telah diberikan cuti selama empat bulan sebagai ganjaran kepada sumbangan beliau yang memastikan pengurusan sekolah berjalan dengan lancar dan baik. Bukan itu sahaja, di bawah pentadbiran beliau, seramai sembilan orang pelajar dari Darjah I hingga VI telah mendapat kelulusan yang cemerlang. Oleh itu, pemberian cuti dalam konteks ini dilihat sebagai salah satu kaedah bagi menghargai usaha guru yang memainkan peranan penting dalam memacu pembentukan modal insan yang berdaya saing.

Di samping itu, kesungguhan Collinge dalam meningkatkan mutu pendidikan Inggeris di Perak juga dapat dilihat melalui usaha beliau yang kerap kali membuat penelitian dan pemantauan terhadap segala aspek yang berkaitan dengan pendidikan. Malahan beliau juga tidak teragak-agak untuk mengkritik sebarang perkara yang dirasakan tidak betul pada tempatnya. Hal ini merujuk kepada kritikan yang pernah dibuat oleh Collinge terhadap kaedah pengajaran yang pernah dilaksanakan di sekolah Inggeris pada tahun $1893 .{ }^{49}$ Pada masa ini, pelajar di sekolah Inggeris dikatakan menghadapi masalah membaca ekoran daripada ketidakcekapan guru semasa mengajar. Menurut Collinge, para guru tempatan dan Eropah didapati menggunakan kaedah pengajaran yang tidak betul iaitu menekankan pelajar di sekolah Inggeris memberi maksud perkataan yang dipelajari dalam bahasa Melayu.Kaedah ini dilihat tidak begitu praktikal bagi pelajar bukan Melayu khasnya pelajar berbangsa Cina dan India. Dalam hal ini, sukar untuk pelajar tersebut menjelaskan makna perkataan bahasa Inggeris dalam bahasa Melayu memandangkan bahasa Melayu bukanlah bahasa ibunda mereka. 


\section{Kesimpulan}

Secara keseluruhan, pendekatan kebajikan yang dilaksanakan oleh Collinge dalam sistem pendidikan di Perak telah berjaya meningkatkan mutu pendidikan di negeri itu. Pendekatan ini bukan sahaja memberi faedah kepada guru, pelajar dan ibu bapa, malahan turut menguntungkan pihak British. Ganjaran berbentuk kenaikan pangkat dan gaji guru yang ditawarkan oleh Collinge bukan sahaja dapat membantu menarik lebih ramai anak muda untuk berkhidmat dalam profesion perguruan, bahkan menjadi daya tarikan utama kepada guru yang sedia ada untuk terus berkhidmat dengan lebih cemerlang. Malahan hasil usaha yang ditunjukkan oleh Collinge telah mendorong pihak British di Perak menambah peruntukan perbelanjaan bagi memajukan tahap pendidikan di Perak pada tahun 1890. Pertambahan peruntukan ini telah menguntungkan pelajar sekolah Inggeris dan sekolah vernakular Melayu. Hal ini dapat dibuktikan apabila Collinge menggunakan peruntukan tersebut secara maksimum bagi kegunaan latihan perguruan, skim gaji dan pencen guru sekolah Inggeris dan sekolah vernakular Melayu malah menjamin masa depan mereka.

Strategi kebajikan yang dilaksanakan oleh Collinge juga telah memberi implikasi yang positif apabila bilangan pelajar yang mendaftarkan diri di sekolah-sekolah dilaporkan semakin meningkat. Begitu juga dengan pertambahan bilangan sekolah yang semakin hari semakin bertambah bagi menampung jumlah pelajar yang semakin ramai di negeri Perak. Hasilnya, lebih ramai tenaga kerja profesional, tenaga kerja separa mahir dan buruh kasar telah berjaya dilahirkan di Perak. Hal ini seterusnya telah memberi sumbangan yang besar kepada pembangunan sosioekonomi di kawasan bandar dan luar bandar di negeri Perak.

Malahan inisiatif yang diambil oleh Collinge dalam memajukan sekolah Inggeris dan sekolah vernakular Melayu di negeri Perak telah dijadikan rujukan oleh Inspector of Schools di negeri-negeri Melayu yang lain seperti Negeri Sembilan dan Selangor. Buku yang dihasilkan oleh Collinge iaitu Manual for teaching Romanised Malay dan Teachers Manual misalnya menjadi rujukan kepada para guru Melayu di Selangor bagi meningkatkan kecekapan dalam aspek pengajaran dan pembelajaran. Hal ini jelas membuktikan Collinge berjaya membawa satu perubahan yang besar dalam sistem pendidikan sehinggakan kaedahkaedah yang diaplikasikan dalam pendidikan menjadi inspirasi kepada negeri-negeri Melayu yang lain. Secara keseluruhan, pelaksanaan pendekatan kebajikan oleh Collinge terhadap guru dan pelajar telah memberi impak kuantitatif dan kualitatif terhadap kemajuan pendidikan Inggeris dan pendidikan Melayu di negeri Perak. Malahan, ia juga memberi impak terhadap pembangunan ekonomi di kawasan bandar dan luar bandar di negeri Perak. Dalam konteks ini, dapat dilihat peranan yang dimainkan oleh seseorang pentadbir iaitu Collinge adalah penting bagi memastikan pelaksanaan dasar-dasar pendidikan yang telah ditetapkan oleh pihak kerajaan dapat berjalan dengan lancar. Malahan sifat beliau yang begitu memahami suasana dan persekitaran negeri Perak pada masa itu juga ternyata telah membantu dalam usahanya untuk meningkatkan tahap pendidikan di negeri tersebut.

\footnotetext{
Nota

${ }^{1}$ Inspector of Schools bermakna, pegawai yang ditugaskan untuk memantau dan memeriksa sekolah bahkan mereka juga melaporkan keadaan dan pencapaian sekolah kepada kerajaan.

${ }^{2}$ Mr. A. Skinner pernah menyandang jawatan sebagai Magistrate of Police and Commissioner of the Court di Seberang Perai (Province Wellesley) sebelum dilantik sebagai Inspector of Schools di NNS pada tahun 1872. Untuk maklumat lanjut sila lihat, Rex Stevenson, Cultivators and Administrators: British Educational Policy Towards the Malay 1875-1906, 1975, Kuala Lumpur: Oxford University Press, 1975, hlm. 32.
} 


\begin{abstract}
${ }^{3}$ Skinner bertanggungjawab membuka lembaran baharu dalam sejarah perkembangan sekolah-sekolah kerajaan Inggeris dan sistem pendidikan Melayu di Negeri-Negeri Selat. Dalam hal ini, kajian ini mendapati bahawa mulai tahun 1870-an, dua buah sekolah rendah kerajaan Inggeris telah dibangunkan semasa berada di bawah pimpinan Skinner, iaitu di Kampung Glam, Singapura dan North Bridge Road, Pulau Pinang dengan masingmasing mempunyai tahap pembelajaran dari tahun I hingga tahun III. Bukan itu sahaja, murid-murid yang lulus peperiksaan tahun III di sekolah-sekolah kerajaan Inggeris sahaja yang mendapat peluang untuk menyambung pelajaran di Raffles Institute dan Penang Free School. Untuk maklumat lanjut sila lihat, D. D. Chelliah, A History of the Educational Policy of the Straits Settlements with Recommendations for a New System Based on Vernaculars, Kuala Lumpur: The Government Press, 1940, hlm. 10.

${ }^{4}$ Guru pelawat Melayu bermaksud guru Melayu yang mempunyai perkhidmatan yang berkualiti dinaikkan pangkat untuk melawat sekolah-sekolah vernakular Melayu. Tugas utama mereka adalah memberi laporan mengenai kemajuan sekolah vernakular Melayu kepada Inspector of Schools. Bukan itu sahaja, mereka juga dikehendaki memastikan standard kurikulum diseragamkan di setiap sekolah vernakular Melayu. Untuk maklumat lanjut, sila lihat, H. S. Barlow, Swettenham, Kuala Lumpur: Southdene Sdn. Bhd., 1995, hlm. 373374.
\end{abstract}

${ }^{5}$ Pejabat Tanah Jajahan (Colonial Office) merupakan sebuah jabatan kerajaan yang mengendalikan hal ehwal tanah jajahan Britain di seluruh dunia. Jabatan ini diketuai oleh Setiausaha Tanah Jajahan ( Secretary of State for Colonies). Pembentukannya dikesan pada tahun 1768 apabila Jabatan Kolonial ditubuhkan bagi menguruskan tanah-tanah jajahan Britain di Amerika Utara. Pada tahun 1782, tanggungjawab tersebut diambil alih oleh Pejabat Dalam Negeri pada tahun 1801. Hal ehwal tanah jajahan Britain dipindahkan pula di bawah bidang kuasa Pejabat Perang. Pejabat ini dinamakan sebagai Pejabat Perang dan Pejabat Tanah Jajahan pada tahun yang sama dengan diketuai oleh seorang Setiausaha Perang dan Tanah Jajahan. Pemecahan Pejabat Perang dan Pejabat Tanah Jajahan berlaku pada tahun 1854. Walau bagaimanapun, Pejabat Tanah Jajahan tidak bertanggungjawab terhadap kesemua tanah jajahan Britain. Ada di antaranya diletakkan di bawah Pejabat India (misalnya India) dan Pejabat Luar Negeri (seperti Mesir). Pada tahun 1902, sebuah divisyen baru telah diwujudkan di Pejabat Tanah Jajahan iaitu Dominion dan mulai tahun 1925, jawatan Setiausaha Hal Ehwal Dominion telah diwujudkan. Kemerdekaan India pada tahun 1947 menyebabkan Pejabat Pejabat Dominion telah disatukan dengan Pejabat India untuk membentuk Pejabat Hubungan Komanwel menjadi Pejabat Komanwel. Dua tahun kemudian, Pejabat Komanwel bergabung pula dengan Pejabat Luar Negeri untuk membentuk Pejabat Luar Negeri dan Komanwel yang kekal hingga kini. Untuk maklumat lanjut, sila lihat Noraini Binti Mohamad Hassan, 'Kesihatan dan Perubatan di Negeri-Negeri Melayu Bersekutu, 1896-1941', Tesis PhD, Jabatan Sejarah, Universiti Malaya, Kuala Lumpur, 2013, hlm, 2.

${ }^{6}$ Sir Frank Atheistance Swettenham (1850-1946) dilahirkan di Belper, Debyshire dan mendapat didikan di England dan Scotland. Beliau telah tiba di Singapura pada tahun 1871 sebagai kadet bagi jajahan Negeri-negeri Selat, dan mempelajari bahasa Melayu dengan seorang Munsyi bernama Mohamed Said. Lima belas bulan kemudian, beliau lulus peperiksaan akhir dan juga mendapat kelayakan sebagai Jurubahasa Mahkamah. Beliau juga mempelajari bahasa Hokkien di samping dilatih dalam kerja-kerja pentadbiran kerajaan. Selain itu, beliau juga pernah berkhidmat di Pejabat Setiausaha Tanah Jajahan di Singapura, ketika Sir Frederick Weld menjadi Gabenor NNS(1880-1887) Dalam tahun 1896, beliau dilantik menjadi Resident General yang pertama sehingga 1901 bagi Negeri-negeri Melayu Bersekutu (NNMB) dan telah memilih Kuala Lumpur sebagai pusat pentadbirannya. Beliau bertanggungjawab memulakan pelbagai pembangunan termasuk sistem pengangkutan kereta api. Pada tahun yang sama beliau memulakan pembinaan Carcosa Seri Negara sebagai tempat kediaman rasminya. Untuk maklumat lanjut, sila lihat H. S. Barlow, Swettenham, hlm.1 dan 369

${ }^{7}$ F.W. Haines dilantik sebagai tutor kepada Sultan dan Raja Muda Selangor sebelum dilantik menjadi Inspector of Schools. Untuk maklumat lanjut, sila lihat: Annual Report of the Selangor for the year 1890, hlm. 32.

${ }^{8}$ Jabatan Pelajaran bermaksud jabatan yang bertanggungjawab mentadbir sekolah dan menguruskan perlantikan pupil teacher (guru pelatih) untuk mengikuti latihan perguruan. Selain itu, jabatan ini juga menasihat sekolah dalam hal yang berkaitan dengan kaedah pengajaran dan perkembangan kurikulum, merancang untuk membangunkan pendidikan, pembinaan sekolah baru, menjalankan penyelidikan mengenai pendidikan serta menyediakan pendidikan dewasa dan pendidikan khas. Malahan, jabatan ini juga mentadbir skim bantuan kewangan dan skim geran.

${ }^{9}$ Annual Report on the State of Perak for the Year 1890, hlm. 16.

${ }_{10}$ Psikologi bermaksud kajian mengenai minda manusia dan fungsinya serta tingkah laku manusia bagi memudahkan pengajaran dan pembelajaran. Untuk maklumat lanjut, sila lihat,http://prpm.dbp.gov.my/cari1?keyword=psikologi (diakses pada 30 Jun 2017).

${ }^{11}$ His Highness the Sultan takes much interest in Malay education, and on my return to Perak, after an absence of some years, he drew my attention to the advance that had been made, and pointed out how easily the Malays 
can be led in such matters by those who understand their character. Sila lihat, C.O. 438/2, Annual Report on the State of Perak for the year 1896, hlm. 23.

${ }^{12}$ Klang 580/83, Regarding the Allowance Grantedly this Government to Rajah Idris, From Resident Selangor to Resident Perak, 1 April 1883.

${ }^{13}$ C.O. 438/1, Annual Report on the State of Perak for the year 1891, hlm.20.

14 Benjamin Peach Keasberry yang merupakan pendakwah agama Kristian, telah membina gereja London Missionary (LMS) di Bras Basah pada tahun 1843. Bukan itu sahaja, beliau juga telah membeli sebidang tanah di Kg. Bencoolen untuk membina misi Gereja kecil Melayu dengan mendapat sumbangan daripada orang ramai. Hal ini menyebabkan murid-murid Melayu yang belajar di Sekolah Keasberry telah memeluk agama Kristian. Keadaan ini telah membimbangkan masyarakat Melayu di Negeri-negeri Selat dan Negeri-negeri Melayu. Untuk maklumat lanjut, sila lihat: D. D. Chelliah, A History of the Educational Policy of the Straits Settlements with Recommendations for a New System Based on Vernaculars, hlm. 3.

${ }^{15}$ C.O. 438/1, Annual Report on the State of Perak for the year 1890, hlm. 16.

${ }^{16}$ Dalam masa keagungan Kesultanan Melayu Melaka, terdapat beberapa orang ulama yang datang ke Melaka dengan tujuan untuk mengembangkan syiar Islam. Mereka sama ada mengajar di istana atau di tempat-tempat kediaman mereka. Sejarah Melayu menyatakan seorang ulama besar dari Makkah bernama Maulana Abu Bakar ke Melaka. Beliau kemudian menjadi guru kepada orang besar Melaka.

${ }^{17}$ Penghulu dilantik oleh raja dan mempunyai kuasa mutlak di peringkat mukim. Jawatan penghulu dipegang oleh seseorang yang memiliki sifat gagah, berani, berharta, serta berasal daripada kerabat atau keturunan pegawai istana. Pendapatannya bergantung kepada hasil cukai yang dikutip daripada penduduk kampungnya, selain hasil daripada kebun atau ladang penghulu itu sendiri. Namun, selepas kedatangan Inggeris, Penghulu menjadi wakil kerajaan di kampung-kampung mereka. Penghulu menjadi penghubung di antara pentadbiran British dengan rakyat (maklumat lanjut, sila lihat,http://cikgustpm.blogspot.com/2013/07/kedudukan-danperanan-penghulu-dalam.html.(tarikh diakses 8 Julai 2015))

${ }^{18}$ Sultan Idris Murshidul Adzam Shah I merupakan Sultan Perak yang ke-28. Baginda memerintah negeri Perak dari tahun 1887-1916. Baginda adalah putera Almarhum Raja Bendahara Alang Iskandar Marhum Teja ibni Almarhum Raja Kecil Tengah Ahmad ibni al-Marhum Sultan Abdul Malik Mansur Shah. Baginda telah diputerakan di Kuala Keboi, Kampar pada tahun 1849. Baginda juga merupakan seorang yang cerdik pandai. Baginda juga mengambil berat terhadap pendidikan masyarakat Melayu. Hal ini menyebabkan sekolah vernakular Melayu berkembang dengan pesat di bawah pemerintahan baginda. Kesungguhan yang ditunjukkan oleh Sultan Idris dalam pendidikan telah menyebabkan kerajaan British meningkatkan peruntukan dalam pendidikan. Sebagai contohnya, pada tahun 1889, kerajaan British telah memperuntukkan \$1,645 daripada jumlah keseluruhan peruntukan perbelanjaan $\$ 2,313,751$ semata-mata untuk membangunkan pendidikan di Perak.

${ }^{19}$ Masyarakat Melayu di negeri Selangor dan Negeri Sembilan didenda sebanyak \$5 sekiranya tidak menghantar anak mereka ke sekolah. Malahan, ibu bapa Melayu yang enggan menurut perintah arahan kerajaan Briitsh pula dipenjarakan.

${ }^{20}$ Rex Stevenson, Cultivators and Administrators: British Educational Policy towards the Malays, hlm. 5.

${ }^{21}$ The Perak Government Gazette, hlm. 16.

${ }^{22}$ Rex Stevenson, Cultivators and Administrators: British Educational Policy towards the Malays, hlm. 8.

${ }^{23}$ Residency 5725/1893, Ask to Obtain Copy of Mr. Collinge's Manual for Teaching Romanised Malay and his teachers Manual, From: Resident, Kuala Lumpur, 22.9.1893, to: The Secretary of Government Taiping, Perak.

${ }^{24}$ Guru agama yang diambil berkhidmat di sekolah vernakular Melayu didapati kurang menguasai aritmetik. Dalam hal ini, timbul sedikit masalah apabila tahap penguasaan aritmerik guru agama yang lemah ini telah memberi kesan terhadap pencapaian pelajar yang didapati turut mengalami masalah yang sama. Hal ini disebabkan di sekolah pondok mahupun madrasah, guru-guru agama ini lebih banyak menumpukan kepada pembelajaran dalam ilmu agama dan bukannya ilmu duniawi. Malahan mata pelajaran yang diajar oleh guruguru agama di sekolah pondok dan madrasah juga lebih kepada mata pelajaran keagamaan seperti muamalat, fardhu ain dan fardhu kifayah. Selain itu, murid-murid di sekolah agama juga diajar menulis dan membaca dalam huruf jawi. Situasi ini seterusnya telah menimbulkan kesukaran kepada guru-guru agama tersebut semasa dalam proses pengajaran. Keterangan lanjut lihat dalam Mohd. Sukeri Bin Hamid, 'Institusi Pendidikan Islam di Kelantan: Suatu Kajian Mengenai Sejarah Perubahan dari Sistem Pondok ke Sistem Sekolah', Tesis Sarjana, Akademik Pengajian Islam, Universiti Malaya, 2004, hlm. 11.

${ }^{25}$ Miscellanouse 3464/94, forward two copies of Collinge Manual of Romanised Malay, from: Ag. Secretary to Government, Perak, 5.10.94, to: The Acting Government Secretary Selangor.

${ }^{26}$ Rex Stevenson, Cultivators and Administrators: British Educational Policy towards the Malays, hlm. 8.

${ }^{27}$ C.O. 438/2, Annual Report on the State of Perak for the year 1896, hlm. 23.

${ }^{28}$ Rex Stevenson, Cultivators and Administrators: British Educational Policy towards the Malays, hlm. 8.

${ }^{29}$ Ray Hutchison, Encyclopedia of Urban Studies, USA: SAGE Publications, Inc., 2010, hlm. 419. 
${ }^{30}$ C.O. 438/2, Annual Report on the State of Perak for the year 1892, hlm.13; C.O. 438/2, Annual Report on the State of Perak for the year 1895, hlm. 15.

${ }^{31}$ Rex Stevenson, Cultivators and Administrators: British Educational Policy towards the Malays, hlm. 8.

${ }^{32}$ Resident Jeneral bermakna seorang pegawai yang berpangkat tinggi dan berkhidmat sebagai pegawai tadbir dalam Jabatan Perkhidmatan Awam. Lihat, maksud 'Resident-general', https://www.merriamwebster.com/dictionary/resident\%E2\%80\%93general (diakses pada 3 Februari 2017).

${ }^{33}$ Ibid.

34 SEL.SEC 2031/1898, Malay Training College Reports, From: British Resident Perak, 3 Mei 1898, to: Residen British Selangor.

${ }^{35}$ Sekolah Perguruan Taiping dibuka pada bulan Jun 1898 khususnya untuk melatih calon guru dari negeri Selangor dan Perak. Dalam hal ini, negeri-negeri yang terlibat telah menghantar seramai lima orang calon guru untuk menerima latihan perguruan di maktab perguruan berkenaan. Pembukaan institusi berkenaan telah meningkatkan bilangan guru terlatih di kedua-dua negeri berkenaan. Malahan, ia juga membolehkan guru-guru Melayu didedahkan cara mengajar yang berkesan berbanding tahun-tahun sebelumnya. Untuk maklumat lanjut sila lihat, Perak Administration Report for the year 1900, by Col. R.S.F.Walker, C.M.G., Acting British Resident, hlm. 19.

${ }^{36}$ Perak Government Gazette, Volume IV-January-June 1891.

${ }^{37}$ The Perak Government Gazette, Volume XI-August-December 1898.

${ }^{38}$ Government of Perak, Estimates of Revenue and Expenditure1891, hlm. 20.

${ }^{39}$ Perak Establishments 1892, hlm. 28.

${ }^{40}$ Annual Report on the State of Perak for the Year 1894, Perak: Government Printing Office, 1895, hlm. 12.

41 Jagjit Singh Sidhu, Administration in the Federated Malay States 1896-1920, Kula Lumpur: Oxford University Press, 1980, hlm. 140.

${ }^{42}$ The Perak Govt Gazette Vol. XI , January-July, 1898, hlm. 12.

${ }^{43}$ Ibid., hlm. 13.

${ }^{44}$ Annual Report on the State of Perak for the year 1890.

${ }^{45}$ Ibid.

${ }^{46}$ Perak Administration Report for the year 1899.

${ }^{47}$ Annual Report on the State of Perak for the year 1896.

${ }^{48}$ Ibid.

${ }^{49}$ C.O. 438/1, Annual Report of the State of Perak for the Year 1893, hlm. 15. 